\title{
KONTEKSTUALISASI WAWASAN ISLAM KEBANGSAAN KIAI ABDUL MUCHITH MUZADI
}

\author{
Ahidul Asror \\ Institut Agama Islam Negeri Jember, Indonesia \\ E-mail: ahd_asr@yahoo.co.id
}

\begin{abstract}
This article seeks to reveal Kiai Muchith Muzadi's thought on the Islamic nationalism in Indonesia. It deals with a number of issues such as state form, the meaning of politics within nation-state life, and the relation of Islam and Pancasila. The article also attempts to answer problematic discourse on contemporary Islam which, within recent decades, (re)rises the principles of nationalism into public discussion. Muchith argues that Negara Kesatuan Republike Indonesia (NKRI/The Unitary State of the Republic of Indonesia) has been an ultimate state form for the Indonesian people. Therefore, this is a duty for the Indonesian Muslims, as Indonesia's majority inhabitant, to actively take a role and involve themselves in guarding Indonesia and its unity. Muchith also sees no relevant necessary to replace the state form with other systems such as khiläfah and Islamic state. To him, politics is a mere means to fight for interests carried out with Islamic principles coupled with nationalism values in order to establish national integration and achieve the shared ideals. Muchith maintains that Pancasila along with its values is compatible with Islam and this is why the Indonesian Muslims should accept it as the state ideology.
\end{abstract}

Keywords: Nationalism of Nahdlatul Ulama; Pancasila; NKRI; Nationalism Politics.

\section{Pendahuluan}

Semenjak awal Nahdatul Ulama (NU) dikenal sebagai organisasi sosio-religius yang kiprahnya tidak dapat dilepaskan dari persoalan kebangsaan. Keputusan menjadi partai politik di masa Orde Lama dan menerima Pancasila sebagai ideologi tunggal dalam Anggaran Dasarnya di masa Orde Baru merupakan bukti bahwa eksistensi NU 
tidak bisa dihindarkan dari segenap masalah kebangsaan. ${ }^{1}$ Kontribusi tokoh NU dalam kehidupan berbangsa juga tidak bisa dipandang remeh. Terpilihnya Abdurrahman Wahid menjadi Presiden RI keempat pada masa reformasi adalah bukti lain dari sekian banyak bukti keterlibatan kader NU. Abdurahman Wahid_-atau yang akrab dipanggil Gus Dur-memiliki mozaik pemikiran Islam kebangsaan yang dirilis dalam beberapa karya. Salah satu karyanya berupa buku berjudul Islam Kosmopolitan. Dalam karya tersebut, Gus Dur menekankan urgensi berpegang teguh kepada nilai universal agama dan menjunjung tinggi sikap inklusif dalam menerima perbedaan. Sikap kebangsaan Gus Dur tampak melalui gagasannya tentang perlunya memahami segala ragam perbedaan. ${ }^{2}$

Berbagai diskursus pemikiran yang mengemuka secara nasional pasca-reformasi juga tidak lepas dari perhatian tokoh-tokoh NU, baik di pusat ataupun di daerah. Di pusat, tokoh-tokoh NU seperti Kiai Hasyim Muzadi, Kiai Said Aqil Sirodj, ${ }^{3}$ dan Kiai A. Mustofa Bisridengan karakteristiknya masing-masing-menarik perhatian akademisi karena mereka mempunyai orisinalitas terkait wawasan pemikiran Islam kebangsaan. Diskursus pemikiran Islam kebangsaan telah mereka tunjukkan dengan kegigihan mensosialisasikan pentingnya mempertahankan Negara Kesatuan Repulik Indonesia (NKRI) yang mengalami ancaman dari ragam gerakan separatis. Secara akademik juga diketahui bahwa pemikiran Islam kebangsaan juga tersebar melalui pemikiran kalangan muda NU, seperti Ulil Abshar Abdalla yang dikenal sebagai pemikir dan inisiator dalam Jaringan Islam Liberal (JIL) di Indonesia. ${ }^{4}$ Pun Musdah Mulia dengan counter legal

1 Lihat tentang sejarah berdiri dan pertumbuhan NU dalam Choirul_Anam, Pertumbuhan-dan Perkembangan NU (Solo: Duta-Aksara Mulia, Cet. Ke-3, 2010). Lihat pula Mitsuo Nakamura, "Krisis Kepemimpinan NU dan Pencarian Identitas Awal 1980-an: Dari Muktamar Semarang 1979 Hingga Muktamar Situbondo 1984", dalam Greg Fealy dan Greg Barton (eds.), Tradisionalisme Radikal: Persinggungan Nahdlatul Ulama-Negara (Yogyakarta: LKiS, 1997), 76-88.

${ }^{2}$ Lihat Agus Maftuh Abegebriel, "Kata Pengantar: Mazhab Islam Kosmopolitan Gus Dur", dalam Abdurrahman Wahid, Islam Kosmopolitan: Nilai-nilai Indonesia dan Transformasi Kebudayaan (Jakarta: The Wahid Institute, 2007), xii-xiii. Baca pula Ellyasa KH. Dharwis (ed.), Gus Dur NU dan Masyarakat Sipil (Yogyakarta: LKiS dan Pustaka Pelajar, 1994).

3 Said Aqil Siradj, Islam Kebangsaan: Fiqih Demokratik Kaum Santri (Jakarta: Pustaka Ciganjur, 1999).

${ }^{4}$ Lihat tulisan-tulisan yang terangkum dalam Ulil Abshar Abdalla, Menjadi Muslim Liberal (Jakarta: Nalar, 2005). Lihat pula pandangan Ulil Abshar Abdalla, 
draft-nya. ${ }^{5}$ Kedua tokoh muda itu sama-sama concern memperjuangkan kesetaraan, kebebasan, dan hak-hak masyarakat sipil dalam semangat demokrasi. ${ }^{6}$

Berdasar penjelasan di atas, dapat disimpulkan bahwa pemikiran Islam kebangsaan adalah wacana yang tidak asing di lingkungan NU. Namun, secara khusus, kertas kerja ini bertujuan mengelaborasi pandangan salah seorang kiai yang cukup mempunyai pengaruh di kalangan warga NU, yakni Kiai Abdul Muchith Muzadi. Topik umum yang dikaji dari Kiai Muchith adalah pandangannya tentang relasi Islam dalam wacana kehidupan berbangsa dan bernegara. Pemikiran Kiai Muchith berkembang karena tantangan yang dihadapi umat Islam Indonesia, khususnya warga NU, semakin kompleks dan membutuhkan pemikiran serius dari orang Islam sendiri yang dipandang memahami bagaimana Islam Indonesia tumbuh dan berkembang. Bagi Kiai Muchith, secara umum, proses penyebaran Islam di Indonesia mempunyai perbedaan dengan proses penyebaran Islam di beberapa kawasan lain, seperti kawasan Timur Tengah, Afrika, dan Eropa. Penyebaran Islam di berbagai kawasan itu lebih diwarnai kekerasan dan bahkan peperangan yang terjadi silih berganti. Kiai Muchith menegaskan bahwa proses penyebaran Islam di Indonesia berlangsung secara damai. Sebagian besar pendakwah awal Islam di Indonesia merangkap sebagai pedagang. Mereka menyampaikan Islam dengan penuh keramahan, kedamaian, dan kebijakan sehingga diterima oleh penduduk dengan suka rela. Kedamaian dan kesukarelaan ini menyebabkan Islam di Indonesia berkembang dan menemukan kembali wajahnya secara utuh sebagai agama yang memberi kerahmahtan untuk semua umat manusia. ${ }^{7}$ Berdasar pandangan umum itu, artikel ini secara khusus mengkaji tentang bagaimana pandangan Kiai Muchith tentang NKRI,

\footnotetext{
"Keragaman dalam Pandangan Islam," dalam Islam Pribumi: Mendialogkan Agama Membaca Realitas (Jakarta: Erlangga, 2003).

5 Lihat Musdah Mulia, Counter Legal Draft, Kompilasi Hukum Islam, Litbang Departemen Agama. Lihat pula tulisan Musdah Mulia, "Islam Agama Rahmat bagi Alam Semesta", Majalab Tabligh Mubammadiyah, Mei 2008.

6 "Mbah Muhith: Soal NII, Pemerintah Masih Ragu", dalam http://www.nu.or.id /post/read/32403/01 Juni 2011/Diakses 24 Oktober 2014. Lihat pula pandangannya tentang terorisme, "Mbah Muhith: Teroris Bukan Cuma Noordin", dalam http://www.nu.or.id/post/read/18563/12 Agustus 2009/diakses 15 September 2011.

${ }^{7}$ Lihat A. Muchith Muzadi, Mengenal Nabdlatul Ulama (Surabaya: Khalista, 2006), 1.
} 
memaknai politik dalam kehidupan berbangsa dan bernegara, dan hubungan Islam dengan Pancasila.

\section{Sketsa Pemikiran Kiai dalam Membangun Islam-Kebangsaan}

Berbagai literatur yang mengkaji tentang kiprah para kiai NU dalam dinamika politik kebangsaan telah dilakukan oleh banyak pakar. Perhatian pengamat baik dalam maupun luar negeri tentang kiprah kiai NU, baik dalam dinamika politik maupun dalam mengembangkan wacana Islam-kebangsaan telah melahirkan beragam tesis. Salah satunya adalah pengakuan bahwa NU dan elitnya mempunyai peran signifikan dalam upaya membangun peradaban bangsa. Melalui perjuangannya yang tulus, telah terukir bermacam prestasi, antara lain peran mereka dalam penyediaan sarana pendidikan yang terjangkau, pemimpin sekaligus motivator bagi masyarakat, dan penjaga tradisi Islam Ahl al-Sunnah wa al-Jamā‘ah. Kepemimpinan para kiai NU tidak bisa dipandang remeh, karena banyak terlahir gagasan mereka yang brilian dalam diskursus pemikiran Islam-kebangsaan. Hal ini diakui peneliti asing, Andree Feillard, yang menyatakan bahwa NU telah berhasil melakukan proses pengintegrasian antara Islam dan negara. Eksistensi organisasi ini juga telah berhasil menyesuaikan ragam dogma Islam terhadap negara-bangsa, yang beban utamanya semenjak kemerdekaan adalah menghindari munculnya disintegrasi bangsa. Melalui ciri khas luwes, NU mampu mengadaptasikan diri dengan ragam tuntutan konstruksi politik Indonesia yang dikenal sangat majemuk, dengan tetap menggunakan kaidah fiqhiyah yang menjadi pola istinbạt hukum dalam tradisi NU, tanpa meninggalkan apa yang menjadi tujuan utama demi mengislamkan rakyat Indonesia. ${ }^{8}$

Selain Andree Feillard, terdapat beberapa studi yang mengetengahkan pemikiran kiai dan tokoh NU tentang diskursus pemikiran Islam-kebangsaan. Misalnya, karya Syamsul Munir Amin berjudul Percikan Pemikiran Kyai. Pemikiran yang diusung oleh para kiai dalam buku tersebut cukup beragam, tetapi di dalamnya memuat perbincangan tentang kebangsaan. Buku tersebut memuat pandangan Kiai Hasyim Asy'ari, Kiai Idham Chalid, Kiai Ali Yafie, dan Kiai Ahmad Siddiq, yang inti pandangan mereka adalah mengembangkan karakter NU sebagai organisasi yang inklusif, adaptif, dan fleksibel.

\footnotetext{
8 Lihat Andree-Feillard, "Nahdlatul Ulama dan Negara: Fleksibilitas, Legitimasi, dan Pembaharuan", dalam Ellyasa KH. Dharwis (ed.), Gus Dur, NU, dan Masyarakat Sipil (Yogyakarta: LKiS dan Pustaka Pelajar, 1994), 1-60.
} 
Dalam kerangka pandangan itu pula, konsep Ahl al-Sunnah wa alJamāah bagi NU dapat dipahami sebagai suatu pengakuan dan penerimaan terhadap tradisi masyarakat Muslim dalam konteks adat di Indonesia, yaitu bagaimana Islam masuk ke Indonesia dalam tradisi mazhab dan dalam aroma yang cukup sufistik. Karya ini mengungkap wawasan kebangsaan kiai NU yang dibangun secara konsisten sehingga dapat menyiasati setiap perubahan situasi sosial-politik nasional. ${ }^{9}$

Pemikiran Islam-kebangsaan model NU juga ditemukan dalam buku Pemikiran KH. Hasyim Asy'ari tentang Abl Al-Sunnah wa al-Jamaah, khususnya dalam konteks hubungan kaum tradisionalis dan modernis di Indonesia. Dinyatakan bahwa semasa Kiai Hasyim identik dengan era pertarungan antara entitas Islam Tradisional (yang diwakili oleh masyarakat pesantren dan mayoritas umat Islam Indonesia yang berafiliasi mazhab Sunni) yang berkontestasi dengan entitas Islam puritan dan pembaru yang dikelompokkan dalam Islam Modernis. Kelompok Tradisionalis maupun Puritan-Modernis sama-sama mengaku sebagai entitas mazhab Sunnī, yang secara geneologis bertemu pada simpul Aḥmad b. $\mathrm{H}\{$ anbal, inisiator mazhab $\mathrm{H}\{$ anbalī. Dalam kehidupan berbangsa yang selalu mengedepankan cita-cita perdamaian, Kiai Hasyim berhasil membawa pemikiran masyarakat tradisionalis mereaktualisir paham Sunn̄i. Studi ini di samping memberikan referensi bagi usaha reaktualisasi paham Sunni dalam kehidupan berbangsa juga menambah menambah khazanah keilmuan baru, yaitu lahirnya konsep "Sunnī Partikular". Konsep ini merupakan ekspresi Ahl Sunnah wa al-Jamā'ah dalam konteks ke-Indonesia-an, sekaligus kontekstualisasi paham Sunn̄̄ yang inklusif, moderat dan fleksibel dalam bersinggungan dengan masalah yang dihadapi ataupun terjadi dalam kesejarahan bangsa, baik pada pra maupun pascakemerdekaan NKRI. ${ }^{10}$

Selain studi-studi di atas, pemikiran Islam-kebangsaan Kiai Hasyim juga berhasil ditulis Zuhairi Misrawi dalam buku yang berjudul Hadratussyaikh Hasyim Asy'ari: Moderasi, Keumatan, dan Kebangsaan. Dalam studi ini, Kiai Hasyim dinyatakan sangat memberi perhatian terhadap kondisi bangsa yang ditunjukkan dengan usahanya mendirikan koperasi, memberdayakan kaum perempuan, dan

\footnotetext{
${ }^{9}$ Lihat Syamsul Arifin Munir, Percikan Pemikiran Para Kyai (Yogyakarta: LKiS, 2009).

${ }^{10}$ Lihat Achmad Muhibbin Zuhri, Pemikiran KH. Hasyim Asy'ari Tentang Abl AlSunnah wa Al-Jamaah (Surabaya: Khalista dan LTN PBNU, 2010).
} 
mendirikan organisasi yang dihuni oleh para ulama di pedesaan. Ia juga menjadi bagian penting bangsa era kolonial yang ditunjukkan dengan pemikirannya, yang memfatwakan wajib hukumnya untuk berjihad melawan Belanda dan haram hukumnya bekerja sama dalam hal apa pun dengan Belanda. Bahkan di zaman penjajahan Jepang, ia berani melawan perintah Jepang untuk melakukan upacara saikerei, yaitu upacara membungkukkan badan setiap pagi ke arah Tokyo untuk menghormat kaisar Jepang dan Dewa Matahari, yang menyebabkannya dipenjara selama empat bulan. ${ }^{11}$

Literatur lain yang telah membicarakan tentang diskursus pemikiran Islam-kebangsaan kiai NU juga ditulis dalam buku karya Said Aqil Siradj yang berjudul Islam Kebangsaan: Fiqih Demokratik Kaum Santri. Buku tersebut menjelaskan tema-tema kebangsaan secara umum dalam tradisi pemikiran Islam tradisional di Indonesia. ${ }^{12}$ Selain literatur-literatur itu, juga ada buku yang ditulis Ali Maschan Moesa dengan berjudul Nasionalisme Kiai: Konstruksi Sosial Berbasis Agama, diterbitkan oleh LKiS Yogyakarta pada akhir tahun 2007. Buku tersebut adalah disertasi dari Ali Maschan Moesa di Universitas Airlangga Surabaya. Buku ini membincangkan tentang pandangan beberapa Kiai Nahdlatul Ulama di Jawa Timur tentang wawasan kebangsaan atau nasionalisme. Hasil riset ini menjelaskan bahwa kiaikiai NU yang diteliti mempunyai pemikiran Islam-kebangsaan, tetapi mereka tetap menyatakan bahwa kecintaan kepada Islam lebih dari kecintaan mereka kepada negara dan bangsa (nasionalisme). ${ }^{13}$

Pemikiran Islam-kebangsaan tokoh NU juga menyentuh ragam persoalan aktual di masyarakat, sebagaimana ditemukan dalam literatur yang ditulis Jamal Ma'mur Asmani tentang pemikiran Kiai Muhammad Sahal Mahfudh dalam buku, Fiqh Sosial Kiai Sahal Mahfudh: Antara Konsep dan Implementasi. Fikih sosial Kiai Sahal merupakan konsep aktif-progresif yang selalu mengacu pada lima prinsip pokok: pertama, interpretasi teks-teks fikih secara konstektual. Kedua, perubahan pola bermazhab dari qawli (tekstual) ke manhaji (metodologis). Ketiga, verifikasi mendasar ajaran yang pokok (usūi) dan yang cabang (fur $\bar{u}^{\top}$ ). Keempat, fikih dihadirkan sebagai etika sosial,

11 Zuhairi Misrawi, Hadratussyaikh Hasyim Asy'ari: Moderasi, Keumatan, dan Kebangsaan (Jakarta: Kompas, 2010).

12 Said Aqil Siradj, Islam Kebangsaan: Fiqih Demokratik Kaum Santri (Jakarta: Pustaka Ciganjur, 1999).

13 Ali Maschan Moesa, Nasionalisme Kiai: Konstruksi Sosial Berbasis Agama (Yogyakarta: LKiS, 2007), 159. 
bukan hukum positif negara. Kelima, pengenalan metodologi pemikiran filosofis, terutama dalam masalah sosial dan budaya. Dengan demikian, fikih bersenyawa langsung dengan af'al al-mukallifin sikap perilaku, kondisi, dan sepak terjang orang-orang Muslim dalam semua aspek kehidupan, baik ibadah maupun muamalah (interaksi sosial ekonomi). Buku tersebut hadir untuk merekam perjalanan Kiai Muhammad Ahmad Sahal Mahfudh semasa hidup dan pergulatan lahirnya diskursus pemikiran Islam-kebangsaan, fiqih sosial yang spektakuler. $^{14}$

Pemikiran Achmad Siddiq tentang Islam-kebangsaan juga pernah dikaji oleh beberapa periset. Mereka menemukan keberhasilan Kiai Siddiq dalam merumuskan secara jelas relasi agung antara Islam dan Pancasila yang pada saat ia hidup menjadi isu kontroversial. Kiai Siddiq menjelaskan secara jernih bahwa Islam adalah agama dan Pancasila hanyalah ideologi an sich. Agama dan Pancasila tidak boleh dicampuradukkan, agama berasal dari wahyu sedangkan ideologi merupakan hasil pemikiran manusia, dan bagaimana pun sebuah ideologi tidak akan pernah mencapai derajat ke tingkat agama. Umat Islam boleh berideologi apa saja asalkan ideologinya itu tidak bertentangan dengan ajaran agamanya. Menurut Kiai Siddiq, agama bisa dimasukkan dalam AD/ART pasal aqidah, sedangkan Pancasila dapat diletakkan pada pasal asas. Baginya, aqidah mempunyai posisi lebih tinggi daripada asas. Pemikiran Islam-kebangsaannya juga dapat dilihat dari keberhasilan membawa NU keluar dari kubangan politik praktis dengan kembali kepada khittah $1926 .{ }^{15}$

Membaca literatur tentang pergulatan pemikiran kiai NU dalam diskursus pemikiran Islam-kebangsaan kurang lengkap kiranya jika tidak membaca buku yang membahas pemikiran Gus Dur, salah satunya, Islam Kosmopolitan: Nilai-nilai Indonesia dan Transformasi Kebudayaan. Dalam karya tersebut, Gus Dur secara tegas melakukan diagnosa situasi nasional-bangsa dan problem keumatan dengan gagasan-gagasannya yang berani dan konstruktif. Wacana pemikirannya sengaja digelindingkan sebagai ikhtiar membingkai kehidupan bermasyarakat dan berbangsa lebih kondusif, ada jaminan

14 Jamal Ma'mur Asmani, Figh Sosial Kiai Sabal Mabfudh: Antara Konsep dan Implementasi (Surabaya: Khalista, 2007).

15 Muhammad AS Hikam, "Khittah dan Penguatan Civil Society di Indonesia: Sebuah Kajian Historis Struktural atas NU Sejak 1984", dalam Greg Fealy dan Greg Barton (eds.), Tradisionalisme Radikal: Persinggungan Nabdlatul Ulama-Negara (Yogyakarta: LKiS, 1997), 133-163. 
hukum yang adil dan terciptanya harmonisasi yang maksimal di antara sesama umat manusia. ${ }^{16}$ Tema-tema pemikiran Gus Dur dalam buku tersebut dibingkai menjadi tiga bagian, di antaranya: (1) ajaran, transformasi pendidikan agama, (2) nasionalisme, gerakan sosial dan anti-kekerasan, dan (3) pluralisme, kebudayaan dan hak asasi manusia. Secara umum, buku tersebut menyatakan pemikiran Gus Dur yang senantiasa mengajarkan nilai universal agama, nasionalisme, dan menjungjung tinggi sikap inklusif terhadap segala kemungkinan menerima perbedaan. Gus Dur mengenalkan khazanah pemikiran yang bebas dari segala bentuk diskriminasi dan kekerasan.

\section{Pandangan Islam Kebangsaan Abdul Muchith Muzadi}

Abdul Muchith Muzadi lahir di Bangilan Tuban, Jawa Timur pada 4 Desember 1925. Kiai yang terkenal dengan gagasan strategis di lingkungan NU ini adalah salah seorang santri langsung dari pendiri NU, Kiai Hasyim Asy'ari. ${ }^{17}$ Semenjak usia muda, Muchith dikenal sebagai sosok kiai dan pejuang NU yang aktif berkiprah di masyarakat. Pada usia 16 tahun, Muchith yang masih belajar di Pesantren Tebuireng sudah tercatat sebagai anggota NU Ranting Tebuireng. ${ }^{18}$ Dari sisi lain, Muchith dikenal masyarakat sebagai sosok kiai dengan penampilan yang sederhana dan bersahaja. ${ }^{19}$ Dalam sejarah NU, Muchith seringkali dikenal sebagai sosok signifikan dalam menyiapkan konsep khittah organisasi NU bersama Kiai Achmad Siddiq dalam tahun 1984 pada muktamar NU ke-28 di Situbondo. Oleh karenanya, pemikiran Muchith cukup berpengaruh dalam perjalanan NU, terutama yang berhubungan dengan ragam masalah keislaman dan kebangsaan.

Muchith lebih banyak menyelesaikan pendidikannya di pesantren. Pada tahun 1935, ketika berumur sepuluh tahun, orang tuanya sudah mengirimnya untuk menimba ilmu di pesantren yang diasuh Kiai Nawawi Kulonbaron Kajen Pati. Di tempat itu, selain modok,

\footnotetext{
16 Abdurrahman Wahid, Islam Kosmopolitan: Nilai-nilai Indonesia dan Transformasi Kebudayaan (Jakarta: The Wahid Institute, 2007).

17 "Muchith Muzadi, Tokoh Perumus Gagasan-Gagasan Strategis NU", dalam http://khazanah.republika.co.id/berita/dunia-islam/islam-nusantara/15/09/06/ (diakses 29 September 2016).

${ }^{18}$ Lihat dalam https://biografi-tokoh-ternama.blogspot.co.id/2015/09/biografi-khahcmad-muchith-muzadi-ulama.html (diakses 25 September 2016).

${ }^{19}$ Lihat dalam Moch. Eksan, Kiai Kelana: Biografi Kiai Muchith Muzadi (Yogyakarta: LKiS, 2000), 59.
} 
Muchith juga melanjutkan sekolah pada madrasah Ibtidaiyah "Miftahul Falah". Di pesantren ini Muchith hanya bertahan selama dua tahun karena pada tahun 1937 ia pindah ke Pesantren Tebuireng Jombang di bawah asuhan Kiai Hasyim Asy'ari. Di tempat ini Muchith turut mengenyam pendidikan di madrasah "Salafiyah Syafi'iyah". Di Pesantren Tebuireng ini, Muchith untuk pertama kalinya bertemu dengan Kiai Achmad Siddiq yang kelak menjadi Rais Aam PBNU. Persahabatan tersebut berlangsung lama hingga keduanya dikenal sebagai dua orang sosok kiai NU berjiwa Islam dan berwawasan nasionalis. ${ }^{20}$

Muchith memandang bahwa umat Muslim Indonesia adalah golongan mayoritas dan karenanya mereka perlu mengisinya dengan sesuatu yang diridai Allah. ${ }^{21}$ Jiwa nasionalisme Muchith sepadan dengan apa yang dikemukakan oleh As'ad Said Ali yang menyatakan bahwa Indonesia diperjuangkan bukan hanya oleh komunitas masyarakat yang memeluk agama Islam, tetapi oleh ragam pemeluk agama, suku, ras dan bahkan oleh rakyat yang berbeda bahasanya. Mereka turut memperjuangkan Indonesia yang merdeka, berdaulat, dan negara yang mandiri bebas dari penjajahan dalam berbagai bentuk dan modelnya. ${ }^{22}$ Oleh karenanya, jika pada saat ini hadir sebagian umat yang menginginkan Indonesia harus berasaskan Islam dan bahkan memiliki undang-undang yang berdasarkan Islam, maka hal itu dapat mencederai konsensus para pendiri bangsa pada 1945. Dalam konteks ini Muchith menyatakan bahwa NKRI merupakan kemufakatan bangsa Indonesia di mana Muslim dan warga NU khususnya harus mengambil peran aktif dalam mempertahankan, melestarikan, dan menjaga keutuhannya. NKRI merupakan upaya final, di mana umat Muslim tidak perlu lagi berkeinginan untuk mendirikan "negara lain" untuk menggantinya.

Menyikapi wacana penegakkan sistem khilafah Islam yang diusung oleh sebagian kelompok Islam di Indonesia, seperti Hizbut Tahrir Indonesia (HTI), Muchith menunjukkan ketidaksetujuannya. Ia menegaskan bahwa kaum pesantren tidak mengikuti pendapat yang mewajibkan seluruh kaum Muslimin sedunia berada di bawah satu

20 Lihat "Kyai Muchith Muzadi dan Achmad Siddiq tentang Pancasila dalam http://www.muslimedianews.com/2015/05/diakses 20 September 2016.

21 Lihat Ayu Sutarto, Menjadi NU Menjadi Indonesia: Pemikiran KH. Abdul Muchith Muzadi (Surabaya: Kompyawisda dan Khalista, Cet. Ke-2, 2008), 35.

22 As'ad Said Ali, Negara Pancasila: Jalan Kemaslabatan Berbangsa (Jakarta: LP3ES, 2009); Sutarto, Menjadi NU Menjadi Indonesia. 
kekuasaan politik. Apa yang terpenting adalah mengembangkan ukhumwah di antara umat Islam (baik secara individual, kelompok maupun pemerintah dalam wujud kerjasama), saling membantu dan menghargai satu sama lain. Kelompok atau bangsa dan atau gabungan antar-bangsa pada dasarnya mendapat kesempatan yang sama untuk mendirikan komunitas politik (negara) sendiri. Dengan kata lain, berbagai kelompok bangsa itu tidak harus menggabungkan diri dengan bangsa lain, ${ }^{23}$ dalam pengertian untuk mendirikan negara tersendiri. Pandangan tersebut dikuatkan pernyataan Muchith bahwa "menjadi NU harus pula menjadi Indonesia". NU lahir dan besar di Indonesia dan telah memiliki komitmen menjaga negeri. Artinya, menjadi NU yang sempurna kata Muchith harus juga memahami apa yang ingin dicapai dan dicita-citakan Indonesia. ${ }^{24}$

Pernyataan Muchith menggunakan kata "kaum pesantren" pada pernyataan di atas, merujuk kepada masyarakat NU yang tidak harus mengikuti pendapat yang mewajibkan bahwa kaum Muslimin sedunia harus berada di bawah satu kekuasaan politik. Rujukan kalimat Muchith tersebut adalah sistem khilafah Islam yang dalam beberapa waktu terakhir marak diperjuangkan oleh kelompok HTI. Sebab, hal itu dapat menggugat kesepakatan bersama yang dibuat oleh para pendiri bangsa. Muchith menambahkan bahwa yang diperlukan bukan kepemimpinan di bawah kendali satu orang. Akan tetapi, yang wajib dikedepankan adalah menjalin persudaraan Islam agar dapat dijaga dan dipelihara dengan baik. Ia menyatakan:

Bangsa Indonesia yang mayoritas Muslim, dibenarkan oleh Islam untuk mendirikan sendiri, karena memang kondisi, kemampuan dan kepentingan kita cukup memenuhi syarat yang wajar bagi berdirinya Negara Indonesia. Oleh karena itulah, di dalam perjuangan melepaskan diri dan penjajahan dan mendirikan negara yang merdeka, kita lakukan dengan mengumpulkan kekuatan dan kemampuan, dengan mendidik dan mempersatukan sekian banyak suku di sekian luas wilayah Indonesia, supaya cukup kekuatan dan kemampuan mengusir penjajahan dan mendirikan negara merdeka yang dapat berdiri tegak bukan untuk satu dua tahun, satu dua abad, tetapi diharapkan untuk sepanjang zaman, karena mempunyai dukungan sumberdaya manusia, sumber daya alam dan rohani yang cukup, di bawah rida Allah. ${ }^{25}$

\footnotetext{
${ }^{23}$ Dikutip dari pendapat Kiai Abdul Muchith Muzadi pada 6 November 2013.

24 Sutarto, Menjadi NU Menjadi Indonesia, 99.

25 Dikutip dari pendapat Kiai Abdul Muchith Muzadi pada 6 November 2013.
} 
Dari pernyataan itu dapat dipahami bahwa umat Islam Indonesia adalah masyarakat mayoritas jika dibandingkan dengan umat beragama yang lain, tetapi mereka tidak memberi ruang untuk gagasan-gagasan mendirikan khilafah Islam. Bagi Muchith, gagasan tersebut memang pernah ada di masa lalu, tetapi sejalan dengan perkembangan waktu, gagasan tersebut perlu mempertimbangkan realitas sekarang. Ia menyampaikan:

Masyarakat Muslimin Indonesia sudah ikut berjuang aktif, bahkan selalu berada di garda terdepan. Kesepakatan yang tercapai pada detik-detik proklamasi adalah kesepakatan di mana kaum Muslimin Indonesia ikut aktif merumuskan dan karena terikat dengan segala kesepakatan itu. Negara Republik Indonesia yang diproklamasikan pada tanggal 17 Agustus 1945 dengan konstitusinya yang lazim disebut dengan Undang-Undang Dasar 1945—dengan serangkaian butir-butir dasar falsafatnya yang disebut Pancasila —adalah negara yang sah menurut ajaran Islam, karena kaum Muslimin yang merupakan mayoritas bangsa dan rakyat Indonesia selalu ikut berjuang mewujudkannya, merumuskan konstitusinya serta memproklamasikannya. Islam mengajarkan memenuhi ikatan janji. ${ }^{26}$

Pandangan Muchith tentang kesepakatan yang tercapai pada detikdetik proklamasi merupakan kesepakatan di mana kaum Muslimin Indonesia ikut aktif merumuskan dan karena terikat dengan segala kesepakatan itu. Negara Republik Indonesia yang diprokamasikan pada tanggal 17 Agustus 1945 dengan serangkaian butir-butir dasar falsafatmya yang disebut Pancasila adalah negara yang sah menurut ajaran Islam. Cara pandang ini merupakan hal yang tidak perlu ditafsirkan ulang. Muchith dalam koteks ini termasuk kiai yang tegas menolak perjuangan HTI untuk mendirikan khilafah Islam. Sebagai tokoh NU yang pemikiran-pemikirannya selalu menjadi rujukan warganya, Muchith menyadari bahwa dia tak akan secara serampangan mengeluarkan pernyataan. Ia memahami bahwa apa yang sampaikan akan dicatat generasi muda dan anak-anak NU secara keseluruhan. Pada saat yang sama, ia menyadari bahwa pandangan tersebut juga akan dijadikan marja' bagi warga nahdliyyin. Dalam uraian selanjutnya, ia menyampaikan hal berikut:

Negara yang sah itu wajib dipertahankan eksistensinya, keamanannya dari bahaya di dalam dan dari luar, dipertahankan keutuhannya, kesatuan dan persatuan rakyatnya serta segala kepentingannya, dengan kesediaan berkorban, baik pikiran, tenaga,

${ }^{26}$ Ibid. 
kekayaan dan jiwa sekalipun. Kewajiban membela dan mempertahankan negara yang sah ini, bukan saja merupakan kewajiban nasional, namun juga kewajiban keagamaan. Islam mengajarkan kewajiban membela dari pribadi (baik secara fisik maupun secara non fisik), membela harta, membela keluarga, di samping membela agama dan negara. ${ }^{27}$

Dari pandangan tersebut, tampak bahwa semangat Kiai Muchith untuk mempertahankan bangsa ini tetap tidak pernah berhenti karena ia sendiri dikenal sebagai kiai yang pernah merasakan perjuangan melawan Jepang. Uraian Kiai Muchith di atas merupakan bukti nyata bahwa sampai kapanpun NU berkomitmen dan bertanggung-jawab dalam mengawal NKRI. Secara khusus, bentuk NKRI yang disebut sebagai bentuk final bagi sistem negara dijelaskan Kiai Muchith sebagai berikut:

Mengapa NKRI dinggap final? Hal itu terkait dengan sejarah perjalanan bangsa ini. Sekarang tidak banyak orang yang mengingat kalau negara kesatuan lawan dari negara federasi yang digagas Belanda dalam Konferensi Meja Bundar. Padahal dulu orang dicap federal itu sama dengan antek Belanda. "Itulah sebab mengapa frasa NKRI menjadi Sakral". Sedangkan lafal "final" bermakna NU tidak ingin mendirikan negara baru pengganti NKRI, baik yang model NII Kartosuwiryo atau Model yang lain". Perkara ngisinya itu masih tetap jalan terus. ${ }^{28}$

Selain bentuk NKRI yang dipandang sudah final, pemikiran Islam kebangsaan Kiai Muchith dapat dilihat dari bagaimana ia memaknai politik dalam kehidupan berbangsa dan bernegara. Negara dalam pandangan Kiai Muchith adalah wilayah urgen dalam melaksanakan ajaran Allah, baik untuk urusan pribadi maupun untuk urusan umat manusia. Oleh karenanya, berpolitik dalam kehidupan berbangsa dan bernegara merupakan sesuatu yang tidak diharamkan. Bahkan, warga negara menurut Kiai Muchith harus didorong dalam kesadaran berpolitik untuk kepentingan masyarakat secara luas, asalkan hal tersebut dilakukan dengan dasar akhlak yang mulia atau budi pekerti yang luhur. Politik menurut Kiai Muchith merupakan kegiatan yang sarat dengan makna yang berhubungan dengan kekuasaan dan pemerintahan. Namun, berpolitik menurutnya tidak seharusnya dilakukan sekadar untuk mendapatkan kursi, jabatan, kedudukan dan

\footnotetext{
27 Ibid.

28 "Kiai A. Muhith Muzadi: Warga Nahdliyin Dukung Pancasila Tolak Khilafah", Majalah Aula, April-2011.
} 
atau perebutan kekuasaan. Pada prinsipnya berpolitik menurut Kiai Muchith adalah berjuang untuk kemanusiaan yang adil dan beradab, berjuang demi persatuan Indonesia, serta berdemokrasi untuk memperjuangkan terwujudnya rasa keadilan sosial. ${ }^{29}$

Kiai Muchith sangat menyayangkan apabila warga negara (khususnya warga NU) berpolitik semata-mata memperebutkan kekuasaan. Berpolitik semestinya lebih mementingkan kepentingan bangsa yang dilandasi dengan spirit Islam. Pada konteks inilah dapat dipahami bahwa aktivitas politik yang diinginkan oleh Muchith Muzadi adalah aktivitas politik warga yang dilandasi oleh akhlak mulia dan senantiasa ditujukan untuk kepentingan bersama. Akhlak berpolitik ditandai dengan upaya terus-menerus memperjuangkan kepentingan warga bukan kepentingan pribadi. Kiai Muchith memberi contoh konkret bagaimana dia bersikap tegas dalam menangani kasus pengolahan tanah Jenggawah, Jember Jawa Timur. Keberaniannya dalam membela pihak PT. Perkebunan di Jember yang berhadapan dengan petani lokal dalam urusan pengolahan tanah garapan melahirkan tuduhan bahwa Kiai Muchith adalah sosok kiai yang "membela pemerintah". ${ }^{30}$ Dalam kasus ini Kiai Muchith menunjukkan keberanian moral yang tinggi meski dia berhadapan dengan tuduhantuduhan miring yang dilamatkan kepadanya. Dalam kasus Jenggawa, Kiai Muchith mengambil sikap politik berbeda dengan cara yang dilakukan oleh partai politik saat itu yang lebih mengedepankan pola agitasi demagogik dalam memperjuangkan kepentingan petani. Dalam kasus tanah Jenggawah, Kiai Muchith mampu dengan jelas menerjemahkan perjuangan dan sikap politik yang bukan semata-mata memperebutkan kursi kekuasaan, tetapi berpolitik adalah memperjuangkan nilai-nilai kebenaran dan keadilan. Politik dalam pengertian sempit (memperebutkan kekuasaan) adalah jalan sesat yang dapat mengakibatkan terjadinya perpecahan bangsa dan keutuhan NKRI.

Kiai Muchith menggarisbawahi bahwa warga negara, khususnya warga NU, perlu memerhatikan pedoman dalam berpolitik. Pedoman tersebut menurut Kiai Muchith dapat dilihat dari hasil keputusan Muktamar NU ke-28 di Krapyak, Yogyakarta. Dokumen muktamar ini antara lain berisikan tentang politik yang diartikan sebagai:

\footnotetext{
${ }^{29}$ Lihat Sutarto, Menjadi NU Menjadi Indonesia, 37.

${ }^{30}$ Lihat Abdurrahman Wahid, Kyai Nyentrik Membela Pemerintah (Yogyakarta: LKiS, Cet. Ke-4, 2010), 11
} 
keterlibatan warga negara dalam kehidupan berbangsa dan bernegara secara menyeluruh sesuai dengan Pancasila dan Undang-Undang Dasar 1945. Di sini, kegiatan politik bagi Kiai Muchith harus dilandasi dengan wawasan kebangsaan menuju integrasi bangsa dengan langkah-langkah yang senantiasa menjunjung tinggi persatuan dan kesatuan untuk mencapai cita-cita bersama, yaitu terwujudnya masyarakat Indonesia yang adil lahir-batin yang dilakukan sebagai amal ibadah menuju kebahagiaan dunia dan akhirat. Demikian pula, berpolitik haruslah dilandasi dengan moral, etika yang berketuhanan Yang Maha Esa, berkepribadian yang adil dan beradab, menjunjung tinggi persatuan Indonesia, berkerakyatan yang dipimpin oleh permusyawaratan perwakilan dan keadilan bagi seluruh rakyat Indonesia. Secara umum, dokumen muktamar yang dikemukakan Kiai Muchith ini berisi tentang tuntutan agar warga negara melakukan komunikasi timbal balik dalam pembangunan nasional untuk menciptakan iklim yang memungkinkan terjadinya perkembangan organisasi kemasyarakatan. ${ }^{31}$

Jika ditilik ke belakang pada era Soekarno, Nahdlatul Ulama sempat dibuat repot dengan eksistensi dan pergerakan Nasakom (Nasionalis, Agamis, Komunis). Saat sang presiden mengumumkan dekritnya dan mengaplikasikan ragam gagasan politiknya, antara lain mengonstruk kabinet yang terdiri dari unsur nasionalis, religius, dan komunis, di mana mereka harus bekerja sama membangun dan mengurus Indonesia, Soekarno akhirnya harus berhadapan dengan kolompok yang menegasikan kebijakan ini, terutama dari kelompok Masyumi. NU—sebagai representasi dari kelompok Muslim-tentu menghadapi pilihan yang tidak mudah, antara terlibat atau keluar dalam kabinet itu. NU jelas akan dituduh sebagai antek Partai Komunis Indoenias (PKI) jika terlibat. Jika pun tidak menyetujuinya, Soekarno akan terus berjalan meski tanpa NU dengan menggandeng kekuatan lain yang mungkin saja tidak mewakili aspirasi umat Muslim dan tentu saja NU. Contohnya pada tahun 1947 ketika Amir Syarifuddin membentuk kabinet dan Masyumi menolak ikut terlibat, Amir lantas mengambil tokoh lain yang diposisikan sebagai wakil dari Islam. Inilah sesungguhnya mengapa terjadi konflik pada partai Masyumi hingga NU akhirnya mengeluarkan diri dari Masyumi pada tahun $1952 .^{32}$

${ }^{31}$ Sutarto, Menjadi NU Menjadi Indonesia, 48-49.

32 Sutarto, Menjadi NU Menjadi Indonesia, 48. 
Pada era Orde Baru, Soeharto melakukan penyederhanaan partai politik menjadi tiga konsestan, Golkar, PPP, dan PDI. Pada waktu itu, NU membebaskan warganya untuk masuk dan berkontribusi pada parpol manapun. Saat itu banya kader-kader NU masuk dan bergabung dengan Partai Persatuan Pembangunan (PPP). Gejalas tersebut munurut Kiai Muhith selalu dipahami secara salah kaprah sebagai khittah NU. Padahal khittah dan perjuangan NU jauh lebih luas dan lebih mendasar daripada sekadar relasi antara NU dengan kekuatan politik tertentu. ${ }^{33}$

Dalam masa reformasi, tekad membangun politik nasional dalam menciptakan iklim yang memungkinkan organisasi sosial-politik berkembang secara mandiri dibuktikan oleh Kiai Muchith dalam proses kelahiran Partai Kebangkitan Bangsa (PKB). Sosok Kiai Muchith tepatnya berperan sebagai salah seorang deklarator untuk berdirinya $\mathrm{PKB}$ yang dikenal sebagai partainya warga NU dalam menyalurkan aspirasi politik kebangsaan. Pengurus Besar Nahdlatul Ulama (PBNU), di mana Kiai Muchith menjadi salah seorang pengurus di dalamnya, tidak membentuk partai tersendiri. Namun, PBNU hanya memberikan pengarahan, bimbingan, dan restu untuk berdirinya sebuah partai yang dapat menampung aspirasi politik warganya. Nama Kiai Muchith yang dikenal sebagai kiai yang berpengaruh tercatat sebagai salah satu sosok deklarator, sebagaimana kutipan berikut:

"Setelah persiapannya matang, maka rapat PBNU pada tanggal 22 Juli 1998 memutuskan dan merestui satu-satunya untuk warga NU, yaitu Partai Kebangkitan Bangsa (PKB). Deklarasi itu berdirinya PKB dilakukan pada tanggal 23 Juli 1998 di Ciganjur Jakarta. Yang mendeklarasikannya bukan PBNU, tetapi para deklarator yang mencerminkan lapisan-lapisan warga NU, KH. M. Ilyas Ruchiyat, K.H. Abdurrahman Wahid, KH. Munasir Ali, KH. A. Mustofa Bisri, dan KH. Abdul Muchith Muzadi...”. ${ }^{34}$

Sebagai tokoh yang telah mendapatkan julukan "literatur hidup NU”, pemikiran Islam kebangsaan Kiai Muchith juga dikenal melalui keikutsertannya dalam menyusun konsep Pancasila sebagai asas tunggal. Sikap dan pemikiran Kiai Muchith bersama Kiai Achmad Siddiq muncul dilatari situasi politik kebangsaan yang dihadapi NU saat itu. Konsep penerimaan Pancasila sebagai asas tunggal tercantum dalam deklarasi yang dibuat pada Musyawarah Nasional Alim Ulama

${ }^{33}$ Ibid., 49.

34 Ibid., 44. 
dan disyahkan dalam Muktamar NU ke-27 tahun 1984 di Situbondo, Jawa Timur. ${ }^{35}$ Kiai Muchith berkeyakinan bahwa lima sila dalam Pancasila sama sekali tidak bertentangan dengan Islam. Bahkan, butir Pancasila secara substansi merupakan bagian dari ajaran Islam, sebagaimana tertulis dalam bukunya:

"Pancasila sebagai dasar dan falsafah Negara Kesatuan Republik Indonesia bukanlah agama, tidak dapat menggantikan agama dan tidak dipergunakan menggantikan kedudukan agama; Sila Ketuhanan Yang Maha Esa sebagai dasar Negara Kesatuan Republik Indonesia menurut pasal 29 ayat (1) Undang-Undang dasar 1945, yang dijiwai sila-sila yang lain, mencerminkan tauhid menurut pengertian keimanan dalam islam; Bagi Nahdlatul Ulama, Islam adalah aqidah dan syariat, meliputi aspek hubungan manusia dengan Allah dan hubungan antar-manusia; Penerimaan dan pengamalan Pancasila merupakan perwujudan dari upaya umat Islam Indonesia untuk syariat agamanya; Sebagai konsekuensi dari sikap di atas, Nahdlatul Ulama berkewajiban mengamalkan pengertian yang benar tentang Pancasila dan pengamalannya yang murni dan konsekuen oleh semua pihak". ${ }^{36}$

Dalam memberikan penjelasan tentang masalah tersebut di atas, Kiai Muchith mengatakan bahwa kalau diucapkan sepertinya Pancasila dapat dianggap sebagai sesuatu yang bertentangan dengan Islam atau setidak-tidaknya tidak islami. Namun, secara jernih ia memaparkan bahwa butir-butir yang ada dalam teks Pancasila tidak satu pun yang bertentangan dengan Islam. Bagi Kiai Muchith, kenyataan inilah yang menjadi dasar penerimaan bagi kelompok nasionalis sekuler dan kelompok nasionalis Islam untuk sama-sama berkonsensus menerima lima sila itu sebagai dasar negara. Ketika pemerintah mengajak semua organisasi berasaskan Pancasila, Kiai Muchith dan organisasi NU pada umumnya menerima ajakan tersebut dengan beberapa pertimbangan, antara lain: pertama, NU semenjak awal didirikan tidak mencantumkan asas organisasi, melainkan menyebut tujuan. NU mencantumkan asas Islam hanya ketika organisasi ini berubah menjadi partai politik pada 1952, seperti halnya partai-partai lain mencantumkan ideologinya. Kedua, Islam bukanlah ideologi. Islam adalah agama Allah, sedangkan ideologi adalah hasil pemikiran manusia. Ketiga, asas sebuah organisasi

35 Lihat Abdul Muchith Muzadi, NU dalam Perspektif Sejarah dan Ajaran: Refleksi 65 Tabun Ikut NU (Surabaya: Khalista, 2007), 75.

36 Ibid., 76. 
tidak harus agamanya. ${ }^{37}$ Inilah beberapa alasan yang menjadi referensi mengapa Pancasila diterima sebagai asas tunggal. Kiai Muchith mempertegas bahwa menjadi NU berarti menerima Pancasila sebagai dasar negara dan bersedia mengamalkannya dengan tulus dan ikhlas. ${ }^{38}$

Dalam buku NU dan Fiqih Kontekstual, Kiai Muchith menyatakan bahwa Pancasila dan agama Islam adalah dua hal yang sejalan dan saling menunjang satu sama lain. Keduanya tidak bertentangan dan tidak boleh dipertentangkan. Dengan kata lain, keduanya tidak harus dipilih salah satunya dengan sekaligus membuang yang lain. Ia mempertegas bahwa Pancasila yang terkandung di dalam Undangundang Dasar 1945 menurut bunyi dan maknanya (bi al-laf: $i$ wa alma'nà al-murād) harus diterima dengan rasa tanggung-jawab. Sikap Muslim Indonesia terhadap Pancasila dalam hubungannya dengan agama memerlukan kejelasan dan kejernihan agar tidak terperangkap dalam sikap yang tidak proporsional. ${ }^{39}$ Kiai Muchith dalam hal ini menyatakan bahwa Muslim Indonesia harus aktif dalam perumusan dan kesepakatan tentang dasar negara dan bahwa nilai-nilai luhur yang telah dirumuskan harus disepakati dan dibenarkan menurut pandangan Islam.

Dalam catatan penulis, wawasan kebangsaan Kiai Muhith dalam konteks relasi agama dan negara itu menawarkan basis pemikiran keumatan dan kebangsaan sebagai sebagai fondasinya. Hal ini bagi penulis sangat relevan. Kiai Muhith lebih mengorientasikan Islam sebagai agama dan umat, bukan agama dan negara. ${ }^{40}$ Basis umat yang plural di Indonesia inilah yang mereferensikan demokrasi dalam sistem bernegara. Hal ini jelas memberikan hak sepenuhnya seluruh umat manusia di hadapan negara, baik yang Muslim atau non-Muslim.

Watak dasar politik atau kekuasaan-tidak terkecuali politik Islam—sesungguhnya hanya akan mendistorsi agama. Bagi penulis,

\footnotetext{
${ }^{37}$ Ibid., 75

38 Sutarto, Pemikiran KH. Abdul Muchith Muradi, 103. Bandingkan bahasan tentang "Mbah Muchith Berbincang tentang NU dan Negara", dalam https://www.nu.or.id /post/read/11600/Diakses 23 Februari 2011.

39 Lihat A. Muchith Muzadi, NU dan Fiqih Kontekstual (Yogyakarta: LKPSM NU DIY, 1994), 95.

40 Bandingkan dengan pemikiran kenegaraan dan keumatan yang ditawarkan oleh Jamāl al-Bannā dalam buku al-Islàm dìn wa ummah, wa laysa dìnān wa dawlatan (Islam agama dan umat, bukan agama dan Negara). Lebih jauh lihat Mukhammad Zamzami, "Islam sebagai Agama dan Umat: Analisa Pemikiran Jamâl al-Bannâ", Teosofi: Jurnal Tasawuf dan Pemikiran Islam, Vol. 1, No. 1 (2011), 93-112.
} 
apa yang diideologikan oleh Kiai Muhith itu mencegah agama terlalu masuk pada area politik, karena ia akan berfungsi sebagai legitimator kekuasaan an sich dan akan bersifat dekonstruktif. Karenanya, ia lebih menekankan pada orientasi kultural agama alih-alih hanya agama yang diorientasikan pada politik dan kekuasaan.

\section{Catatan Akhir}

Bagi Kiai A. Muhith Muzadi, Negara Kesatuan Republik Indonesia merupakan bentuk final yang dihasilkan melalui kesepakatan bersama di antara para pendiri bangsa. Karena itu, setiap warga negara harus mengambil peran aktif dalam mempertahankan kelestarian dan menjaga keutuhannya. Muslim Indonesia tidak perlu mengganti sistem NKRI dengan bentuk atau sistem lain. Sebagai kelompok mayoritas, mereka hanya perlu mengisi NKRI dengan sesuatu yang bermanfaat. Mereka tidak harus mengikuti pendapat yang mewajibkan bahwa umat Islam sedunia berada dalam satu wadah kekuasaan politik yang disebut khilafah. Apa yang terpenting dalam kehidupan berbangsa adalah berkembangnya persaudaraan di antara warga, saling membantu dan menghargai satu sama lain.

Politik dalam kehidupan berbangsa dan bernegara merupakan sesuatu yang penting dalam demokrasi dan karenanya tidak diharamkan bagi umat Muslim Indonesia. Berpolitik diperlukan dalam memperjuangkan kepentingan masyarakat secara luas serta dilakukan dengan prinsip akhlak atau budi pekerti yang luhur. Prinsipnya, berpolitik adalah berjuang untuk kemanusiaan yang adil dan beradab dalam negara kesatuan yang demokratis dan bertanggung jawab. Karenanya, kegiatan politik harus dilandasi dengan moralitas Islam dan wawasan kebangsaan menuju terwujudnya integrasi bangsa dengan langkah-langkah yang senantiasa menjunjung tinggi nilai-nilai persatuan dan kesatuan bangsa untuk mencapai tujuan dan cita-cita bersama.

Islam dan Pancasila dalam kehidupan berbangsa dan bernegara adalah sesuatu yang tidak bertentangan satu sama lain. Islam adalah agama yang datangnya dari Allah, sedangkan Pancasila adalah buah pemikiran manusia yang kemudian disebut dengan ideologi negara. Keduanya tidak dapat saling menggantikan posisi. Artinya, Pancasila bukan agama dan sampai kapan pun ia tidak dapat menggantikan posisi agama. Seluruh sila yang terdapat di dalam Pancasila tidak bertentangan dengan ajaran Islam dan sudah disepakati fungsinya 
sebagai dasar negara: harus diterima dengan rasa tanggung-jawab. Sikap Muslim Indonesia terhadap Pancasila dalam hubungannya dengan agama harus proporsional. Oleh karena itu, Muslim Indonesia harus menerima Pancasila serta mengamalkan nilai di dalamnya secara bertanggung jawab.

\section{Daftar Rujukan}

"Kiai A. Muhith Muzadi: Warga Nahdliyin Dukung Pancasila Tolak Khilafah”, Majalah Aula, April-2011.

"Kyai Muchith Muzadi dan Achmad Siddiq tentang Pancasila dalam http://www.muslimedianews.com/2015/05/diakses 20 September 2015.

"Mbah Muchith Berbincang tentang NU dan Negara", dalam https://www.nu.or.id/post/read/11600/Diakses 23 Februari 2011.

"Mbah Muhith: Soal NII, Pemerintah Masih Ragu", dalam http://www.nu.or.id/post/read/32403/01 Juni 2011/Diakses 24 Oktober 2014.

"Mbah Muhith: Teroris Bukan Cuma Noordin", dalam http://www.nu.or.id/post/read/18563/12 Agustus 2009/ diakses 15 September 2011.

"Muchith Muzadi, Tokoh Perumus Gagasan-Gagasan Strategis NU", dalam http://khazanah. republika.co.id/berita/dunia-islam/islamnusantara/15/09/06/diakses 29 September 2016.

Abdalla, Ulil Abshar. "Keragaman dalam Pandangan Islam," dalam Islam Pribumi: Mendialogkan Agama Membaca Realitas. Jakarta: Erlangga, 2003.

Abdalla, Ulil Abshar. Menjadi Muslim Liberal. Jakarta: Nalar, 2005.

Abegebriel, Agus Maftuh. "Kata Pengantar: Mazhab Islam Kosmopolitan Gus Dur", dalam Abdurrahman Wahid, Islam Kosmopolitan: Nilai-nilai Indonesia dan Transformasi Kebudayaan. Jakarta: The Wahid Institute, 2007.

Ali, As'ad Said. Negara Pancasila: Jalan Kemaslahatan Berbangsa. Jakarta: LP3ES, 2009.

Anam, Choirul. Pertumbuban dan Perkembangan NU. Solo: Duta Aksara Mulia, Cet. Ke-3, 2010.

Asmani, Jamal Ma'mur. Fiqh Sosial Kiai Sahal Mahfudh: Antara Konsep dan Implementasi. Surabaya: Khalista, 2007. 
Dharwis, Ellyasa KH. (ed.), Gus Dur NU dan Masyarakat Sipil. Yogyakarta: LKiS dan Pustaka Pelajar, 1994.

Eksan, Moch. Kiai Kelana: Biografi Kiai Muchith Muzadi. Yogyakarta: LKiS, 2000.

Feillard, Andree "Nahdlatul Ulama dan Negara: Fleksibilitas, Legitimasi, dan Pembaharuan", dalam Ellyasa KH. Dharwis (ed.), Gus Dur, NU, dan Masyarakat Sipil. Yogyakarta: LKiS dan Pustaka Pelajar, 1994.

Hikam, Muhammad AS. "Khittah dan Penguatan Civil Society di Indonesia: Sebuah Kajian Historis Struktural atas NU Sejak 1984”, dalam Greg Fealy dan Greg Barton (eds.), Tradisionalisme Radikal: Persinggungan Nabdlatul Ulama-Negara. Yogyakarta: LKiS, 1997.

Misrawi, Zuhairi. Hadratussyaikh Hasyim Asy'ari: Moderasi, Keumatan, dan Kebangsaan. Jakarta: Kompas, 2010.

Moesa, Ali Maschan. Nasionalisme Kiai: Konstruksi Sosial Berbasis Agama. Yogyakarta: LKiS, 2007.

Mulia, Musdah. "Islam Agama Rahmat bagi Alam Semesta", Majalah Tabligh Muhammadiyah, Mei 2008.

Mulia, Musdah. Counter Legal Draft, Kompilasi Hukum Islam, Litbang Departemen Agama.

Munir, Syamsul Arifin. Percikan Pemikiran Para Kyai. Yogyakarta: LKiS, 2009.

Muzadi, A. Muchith. Mengenal Nabdlatul Ulama. Surabaya: Khalista, 2006.

-----. NU dalam Perspektif Sejarah dan Ajaran: Refleksi 65 Tahun Ikut NU. Surabaya: Khalista, 2007.

Muzadi, A. Muchith. NU dan Fiqih Kontekstual. Yogyakarta: LKPSM NU DIY, 1994.

Nakamura, Mitsuo. "Krisis Kepemimpinan NU dan Pencarian Identitas Awal 1980-an: Dari Muktamar Semarang 1979 Hingga Muktamar Situbondo 1984", dalam Greg Fealy dan Greg Barton (eds.), Tradisionalisme Radikal: Persinggungan Nabdlatul Ulama-Negara. Yogyakarta: LKiS, 1997.

Siradj, Said Aqil. Islam Kebangsaan: Fiqih Demokratik Kaum Santri. Jakarta: Pustaka Ciganjur, 1999.

Sutarto, Ayu. Menjadi NU Menjadi Indonesia: Pemikiran KH. Abdul Muchith Muradi. Surabaya: Kompyawisda dan Khalista, Cet. Ke-2, 2008. 
Wahid, Abdurrahman. Islam Kosmopolitan: Nilai-nilai Indonesia dan Transformasi Kebudayaan. Jakarta: The Wahid Institute, 2007.

-----. Kyai Nyentrik Membela Pemerintah. Yogyakarta: LKiS, Cet. Ke-4, 2010.

Zamzami, Mukhammad. "Islam sebagai Agama dan Umat: Analisa Pemikiran Jamâl al-Bannâ", Teosofi: Jurnal Tasawnf dan Pemikiran Islam, Vol. 1, No. 1, 2011.

Zuhri, Achmad Muhibbin. Pemikiran KH. Hasyim Asy'ari Tentang Abl Al-Sunnah wa Al-Jamaah. Surabaya: Khalista dan LTN PBNU, 2010. 